\title{
Globaali oppiminen
}

TAPIO VARIS

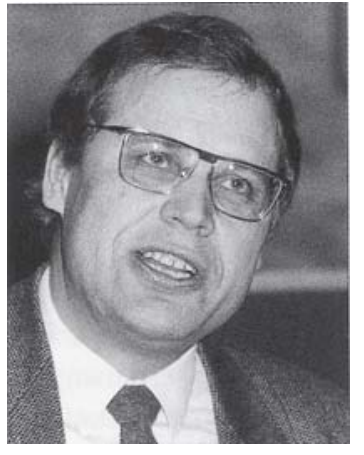

"Usean vuosikymmenen ajan on esitetty voimakasta kritiikkiä siitä, että perinteinen sivistysyliopisto on saanut äistyä markkinamallisen ja yrityshenkisen yliopiston tieltä. Olisi kuitenkin outoa, jos sivistyksen ja elinkeinoelämän tarpeiden välillä olisi ylipääsemätön ristiriita. Tiede ja teknologia ovat inmiskunnan historiassa kukoistaneet erilaisissa kulttuureissa ja niin tapahtuu tulevaisuudessakin", kirjoittaa Tapio Varis. Globaalia oppimista käsitellevä Varis uskoo, että 2000-luvulla on syntymässä uusi renessanssikasvatus, joka suuntautuu uutta luovaan hyvän elämän rakentamiseen. oulukuun alussa päättyneessä korkeakoulutuksen maailmankokouksessa UNESCO:ssa kysyttiin, ovatko yliopistot nykymuodossaan uhanalainen, katoamassa oleva laji (UNESCO Forum 2006). The Guardian -lehdessä Oxfordin yliopiston professori Timothy Garton Ash kysyi kriittisesti, mahtaako Euroopassa olla yhtään maailmanluokan tutkimusylipistoa 20 vuoden kuluttua. Euroopassa kyllä puhutaan tietoyhteiskunnasta, mutta amerikkalaiset kulkevat sitä tietä ja aasialaiset tulevat perässä. (The Guardian 30. November 2006). Haaste lienee kaikille selvä: Kiina ja Intia hakevat uudelleen sitä asemaa maailmantaloudessa, joka niillä oli parisataa vuotta sitten ja Yhdysvallat haluaa säilyttää hegemoniansa. Yliopistojen tulisi kuitenkin myös vaikuttaa siihen, minkälaista yhteiskuntaa rakennetaan.

Euroopan Unioni on vuosille 2007-2013 omaksunut integroidun elinikäisen oppimisen ohjelman (The Integrated Lifelong Learning Programme - ILLP), jossa e-oppiminen nähdään laaja-alaisena digitaalisena kompetenssina. Informaatio- ja viestintäteknologian uskotaan eri tavoin tukevan kasvatusta, taidetta, tiedettä, liikeelämää ja teollisuutta (Gutierrez 2006, s. 146147). E-oppimisen ei enää ensisijaisesti viittaa sähköiseen oppimiseen, vaan tehostettuun oppimiskokemukseen uusien teknologien mahdollistamien medioitten avulla (enhanced learning experience through the medium of new technologies, IST 2006).
Kehitys verkoissa tapahtuvien, avoimien oppimisympäristöjen maailmassa on niin nopeaa, että esimerkiksi virtuaaliyliopisto on saanut uusia Wikipediasta kehitettyjä haasteita kuten Wikiversity, vapaiden oppimateriaalien ja toimintojen luomisen ja käytön yhteisö, jossa "opettajat oppivat, ja oppijat opettavat" (http://beta. wikiversity.org). Se kuten myös vapaiden ja avoimien ohjelmistolähteiden (Free and Open Source Software-FOSS) edistäminen ovat esimerkkejä avoimien oppimis- ja opetusresurssien kehittämisen haasteista(Open Educational ResourcesOER).

Koulutuksessa yleensä on jo kymmeniä vuosia jatkunut intellektuaalisia sisältöjä, instituutioita ja pedagogisia käytäntöjä ravistellut muutosprosessi, joka koskettaa myös ammattikasvatusta. Oppijakeskeinen elinikäinen oppiminen korostaa uusien valmiuksien ja oppimistaitojen merkitystä myös työelämässä.

Käsite "globaali oppiminen" tuli kansainvälisen huomion kohteeksi vuosina 1981-1986, kun sille muodostettiin YK-yliopistossa oma osastonsa. Tuo alkuvaihe ei vielä silloin onnistunut tavoitteissaan, vaikka nykyisin samantapaisia periaatteita toteutetaan verkossa (on-line-learning).

Käsittelen näitä tavoitteita ammattikasvatuksen haasteiden näkökulmasta.

Vuonna 1997 virkaanastujaisesitelmäni aihe oli "Ajatuksia mediakulttuurista ja viestintäkasvatuksesta". Keskityin amerikkalaisen John Deweyn filosofiaan kasvatuksen ja viestinnän suh- 
teista. Mieluisa yhteys aikaisempiin ajatuskulkuihini syntyi Turkissa hiljattain kuullessani, että kun uutta Turkkia luotiin ja maassa oli noin 10 prosentin lukutaito, sinne kutsuttiin vuonna 1924 ulkopuolisena asiantuntijana John Dewey. Hän suositteli etäopetuksen keinojen tehokasta hyödyntämisestä Turkin takapajuisuuden voittamiseksi. Kasvatusfilosofi Dewey varmaankin olisi nykypäivänä edistämässä e-oppimisen ja muiden uusien menetelmien globaalia hyväksikäyttöä.

Suuret tieteelliset mullistukset tulevat usein yliopistolliseen tiedeyhteisöön sen reuna-alueilta tai suorastaan yliopiston ulkopuolelta. Energiaa ja elinvoimaa tuli yliopistoihin niiden ulkopuolelta. Renessanssiajattelun kannalta tämä ei ole uusi havainto, sillä myös 1600-luvun filosofia ja luonnontieteellinen uudistuminen (Descartes, Spinoza, Leibniz, Pascal, Kepler) tulivat kaikki skolastisten yliopistojen ulkopuolelta, kuten Saksan yliopistomaailmaa 1990-luvulla ravistellut professori Peter Glotz on kirjoittanut (Glotz 1996, 41).

Ammattikasvatus, erityisesti kansainvälistyvät oppimisympäristöt muodostuu haasteeksi jo käännettäessä nimikettä englannin kielelle. Englannin kielen sana vocational ei perinteisessä mielessä riitä kattamaan professionaalisuuden merkityksiä. Jopa Jürgen Habermasille intellektuaalinen elämä on ennen kaikkea ammatillista kutsumusta (vocation) (Pusey 1987, 14). Englannin kielessä sana technical liitetään ammatilliseen koulutukseen.

Minkälaisia intellektuaalisia ominaisuuksia ja lahjakkuuden ulottuvuuksia ammatillisessa osaamisessa nyt tarvittaisiin? Informaatioon ja tietoon sekä globaaleihin verkostoihin perustuva yhteiskunta tuo osaamiseen uusia intellektuaalisia haasteita, eivätkä teollisuusyhteiskunnassa määritellyt ammatit ole välttämättä 2000-luvun osaamisen alueita. Ammattiin liittyy entistä enemmän yrittäjyyttä. Professori Pekka Ruohotie on korostanut, että ammateissa tarvittavien kvalifikaatioiden kehittymistä on tarkasteltava ensisijaisesti oppimisprosessien näkökulmasta ja toissijaisesti alakohtaisen substanssitiedon näkökulmasta. Ammatteja ei voi pitää myöskään ulkoapäin tuotantoelämästä annettuina, vaan niiden kehittymiseen voidaan ja tuleekin vaikuttaa ammattikasvatuksen avulla (Ruohotie 2000, 284).

Käsittelin Ammattikasvatuksen aikakauskirjassa no 1/2006 julkaisemassani artikkelissa"Ammatillisen osaamisen intellektuaaliset haasteet" ammattikasvatuksen tieteellistä luonnetta ja sen suhdetta nykyiseen käsitykseen tiedosta. Pekka Ruohotie on korostanut ammattikasvatuksen tutkimisen poikkitieteellisyyttä. Itse olen käyttänyt yhä enemmän käsitettä transdisiplinäärisyys. Tällä olen halunnut korostaa sitä, että tiedollisessa ja taidollisessa osaamisessa yhä enemmän merkitsevät myös tunne-elämään vaikuttavat taiteelliset ominaisuudet ja käden taitoihin perustuva taidollinen osaaminen. Olen suosinut uusrenessanssikasvatuksen ideaa (Varis 2005).

Ruohotien mukaan keskeisenä tutkimuskohteena ovat olleet mm. koulutuksen ja työelämän suhteet, jotka edellyttävät kasvatustieteen ohella mm. sosiologista ja taloustieteellistä näkökulmaa sekä eri alojen substanssitieteiden, kuten tekniikan tai hoitotieteen lähestymistapaa. Ruohotie jopa kysyy, onko ammattikasvatus osa tuotannon infrastruktuuria vai kasvatuksellisiin arvoihin sitoutunutta toimintaa. Tämä ristiriita on ollut läpikäyvänä juonteena koko ammatillisen koulutuksen historian ajan kaikkialla (Ruohotie 2000, 285).

Professori Anja Heikkinen tarkasteli vuonna 2000 suomalaisen ammattikasvatuksen alkuvaiheita nykypäivän haasteiden kannalta. Tällaisia ovat hänen mukaansa suomalaisuuden korvautuminen eurooppalaisuudella, ammatillisen työllistyvyydellä ja asiantuntijuudella ja kasvatuksellisen elinikäisellä oppimisella (Heikkinen 2000, 11). Kansainvälisellä tasolla pohditaankin yhä enemmän osaamisen laatua ja relevanssiutta sekä eurooppalaisen työvoiman että globaalin kilpailun kannalta (Unesco-Unevoc 2005). Aina on tiedetty, että kansakuntien välisen menestymisen kilpailussa ratkaisevaa on maan kasvatus- ja koulutusjärjestelmä kokonaisuudessaan.

\section{$\mathrm{G}$}

lobaalisuus on meneillään oleva prosessi, jonka suunta määräytyy paljon monikansallisten yritysten ja teknologiateollisuuden toiminnalla, tutkimuksella, ja eduilla. Tanskalaiset tutkijat kiteyttävät globalisaation paradoksit kolmen ryhmittymän kansainvälisiin suhteisiin. On LänsiEuroopan ja Japanin nopeasti kasvava, ikääntyvä, mutta varakas ihmisryhmä. On olemassa nopeasti vaurastuva ja tuottava nuorten ihmisten joukko Kiinassa ja Intiassa. Intiassa arvioidaan maan työvoiman lisääntyvän seuraavan kymmenen vuoden aikana 90 miljoonalla hengellä, mikä aiheuttaa paineita kasvatusjärjestelmälle (The Times of India 6.12. 2006). Kolmanneksi on suu- 
ri joukko nuoria ihmisiä suuren syntyvyyden, mutta alhaisen talouden maissa, joilla on vain niukasti mahdollisuuksia saada minkäänlaista kasvatusta ja joiden tyytymättömyys ja katkeruus kasvavat nopeasti. (The Danish National Commission for Unesco 2006).

Yliopistot joutuvat uudella tavalla vastaamaan ammatillisuuden haasteisiin. Usean vuosikymmenen ajan on esitetty voimakasta kritiikkiä siitä, että perinteinen sivistysyliopisto on saanut väistyä markkinamallisen ja yrityshenkisen yliopiston tieltä. Suomessa esimerkiksi tieteentekijöiden liiton puheenjohtaja Antero Puhakka havaitsee, että yhteiskunta ei enää jaa samoja ihanteita eikä näe tavoiteltavanarvoisena samoja asioita, joita yliopistoissa on totuttu tavoittelemaan (Puhakka 2006).

Olisi kuitenkin outoa, jos sivistyksen ja elinkeinoelämän tarpeiden välillä olisi jokin ylipääsemätön ristiriita. Keskiaikainen yliopisto on joka tapauksessa kulkenut tiensä päähän samalla tavalla kuin perinteinen kansallisvaltio tai kirkko. Elinkeinoelämän keskusjärjestöt ovat jo havainneet, että työelämässä tarvitaan tietyn alan ydinosaamisen lisäksi kykyä toimia laaja-alaisesti. Digitalisoitavissa olevat palvelut siirtyvät verkkoon ja niiden markkinat ovat globaalit. Haasteena on toisaalta antaa työelämävalmiudet koko ikäluokalle sekä tuottaa korkeatasoista ja nykyistä laaja-alaisempaa osaamista sekä ammatillisessa että korkea-asteen koulutuksessa (EK 2006). Nyt työvoiman odotetaan hallitsevaan informaatio- ja viestintäteknologian vaatimia taitoja, vaikka esimerkiksi vuonna 2006 tehtyjen selvitysten mukaan 37 prosenttia eurooppalaisista 16-74 vuotiaista ei ole työelämän edellyttämiä digitaalisia taitoja. (Eurostat 2006).

Eurooppalaisen sivistysyliopiston kehittelijä Wilhelm von Humboldt oli poliitikko ja hallintomies, joka halusi suojata yliopiston ammatillisuudelta ja siihen perustuen akateemisessa koulutuksessa on esiintynyt vastustusta ajatukselle kasvatuksen hyödyllisyydestä esimerkiksi elinkeinoelämän kannalta. Seurauksena on kuitenkin ollut yliopistojen innovatiivisuuden heikkeneminen ja jopa niiden kiinnostavuuden väheneminen (Rauner 2006). Energia ja elinvoima puuttuvat.

Kansainvälistyvät oppimisympäristöt kääntyvät englanniksi sanoilla global learning environments. Usko globaaliin e-oppimiseen on vahva, vaikka yritykset luoda uudenlaisia virtuaaliyli- opistoja kaatuvat toinen toisensa jälkeen. Saattaa olla, että perinteinen yliopisto onkin uusien oppimisympäristöjen kehittelyssä jäämässä sivuraiteelle. Yhdysvalloissa on kongressille ehdotettu 1 miljardin dollarin vuosittaista rahoitusta e-oppimismateriaalien kehittelyä varten. Tämä rahoitus ei menisi perinteisille yliopistomaisille aloille, vaan kohdistuisi ammatillisen työvoiman uudelleenkoulutukseen, elinikäisen oppimisen tukemiseen sekä erilaisiin yleisen turvallisuuden vaatimiin koulutustarpeisiin. (Feldstein 2006)

Etelä-Korea on jo vuosia panostanut maailmanlaajuisien e-oppimismarkkinoiden valtaukseen. Myös esimerkiksi Kiinassa, Intiassa. Brasiliassa, Etelä-Afrikassa ja Venäjällä hyödynnetään uuden teknologian mahdollistamia, verkottuvia ja digitalisoituvia oppimisympäristöjä. Vain muutama päivä sitten esitelmöin digitaalisia kirjastoja käsitelleessä kansainvälisessä kokouksessa Intiassa. Intian ja Kiinan ohella myös Egypti on näyttävästi elvyttänyt tiedon tallentamisen uutta teknologiaa. Näissä ikivanhoissa kulttuureissa ymmärretään, että tietoyhteiskunnan rakentaminen merkitsee kulttuurin ja sosiaalisen osaamisen keskeistä mukanaoloa. Myös traditionaalisten tietojärjestelmien säilyttäminen on tärkeää (ICDL 2006). Euroopassa oppimisympäristöjen kehittäminen on osa Lissabonin strategiaa. Haasteet ovat kuitenkin globaaleja. Esimerkiksi Portugali on tehnyt sopimuksen yhdysvaltalaisen MIT-yliopiston kanssa järjestelyistä, joka tuo MIT:n opetuksen ja tutkimuksen osaksi maan korkeakouluopetusta.

Entä jos digitaalista lukutaitoa vastustava tai kehityksestä muuten syrjäytyvä nk. off-the-grid joukko kasvaakin kovin suureksi? Onko mielekästä pohtia globaalia oppimista aikana, jossa globalismia vastustavat kansalaisliikkeet ja länsimaisia arvoja torjuvat kulttuurit saattavat kyseenalaistaa nykyisen globalisaatioprosessin? Kannattako edistää globaalia e-oppimista, jos nykyiset e-oppimisjärjestelmät epäonnistuvat sosiaalisesti ja teknisesti? Onnistuuko Bologna-prosessin edellyttämien transnationaalisten oppimisympäristöjen luominen? Näitä ja monia muita skenarioita arvioidaan esimerkiksi Englannin avoimen yliopiston vuoteen 2012 ulottuvassa suunnittelumuistiossa ja ne askarruttavat ammattikasvatuksen suunnittelijoita maailmanlaajuisesti (The Open University Scenarios 2003-2012).

Oma taustani on viestintätieteissä. Ammattikasvatuksen läheisyys elinkeinoelämään, tuotan- 
toon ja yhteiskuntaan yleensä tarkoittaa, että liikumme monessa mielessä yhteiskuntapolitiikan alueilla. Kuten professori Hannele Niemen kirjoittaa, kasvatustieteeseen on aina kuulunut ajatus siitä, että kasvatuksella on pyrittävä johonkin suuntaan (Niemi 2002, 40). Myös ammattikasvatus on normatiivista, koska ihmisen ammatilliseen kasvuprosessiin halutaan vaikuttaa. Suunnaksi ei mielestäni riitä osaavan työvoiman kouluttaminen, vaan siihen vaaditaan syvempää arvopohdintaa.

Globaalin yliopiston kehittämisessä huomio kohdistuu oppimiseen ja sen teknologiasuhteeseen. Professorit Sanna Järvelä, Päivi Häkkinen ja Erno Lehtinen ovat tämän oivaltaneet uudessa teoksessaan "Oppimisen teoria ja teknologian opetuskäyttö" (2006). He kirjoittavat, että teknologian opetuskäytön tutkimusta, kuten kasvatustieteellistä ja oppimisympäristöihin liittyvää tutkimusta yleisemminkin, on usein kritisoitu siitä, ettei se ole kyennyt tuottamaan riittävän hyvin perusteltuja ja uskottavia ratkaisuja ajankohtaisiin ongelmiin ja kehittämishaasteisiin. Esimerkkinä uusista suuntauksista he mainitsevat toimintatutkimuksen rinnalle nousseen designtutkimuksen.

Ajankohtaisia tehtäviä avoimien ympäristöjen kehittämisessä ovat nyt oppimisympäristöjen suunnittelu (learning design solutions), laadunvarmistus (quality assurance), kompetenssien sertifiointi (certification of competences), sekä erilaisten käyttäjien voimaantumista edistävät toimet (empowering users).

Jlobaali oppimisen -lähestymistavan alkuvaiheet opin jo 1980-luvun puolivälissä, kun minut valittiin YK:n yleiskokouksen perustaman Rauhanyliopiston ensimmäiseksi rehtoriksi Costa Ricaan vuonna 1986. Käsitteen keskeinen kehittelijä oli YK-yliopiston silloinen vararehtori ja ruotsalainen kollegani Edward Ploman.

Vuonna 1984 minut oli kutsuttu esitelmöimään Lontoon yliopiston kasvatustieteelliseen tiedekuntaan maailman televisio-ohjelmistoista. Oma esitykseni julkaistiin The Jounal of Moral Education -lehdessä erikoisnumerossa, joka keskittyi televisioviestinnän ja etiikan ongelmiin (Varis 1984). Pääesitelmöitsijä oli kuitenkin Edward Ploman, joka esitteli YK-yliopiston uuden "globaalin oppimisen" -jaoston toimintaperiaatteita. Olin tuntenut Plomanin jo aikaisemmilta ajoilta, ja minun oli helppo samaistua hänen ajat- teluunsa. Hänen erikoisalansa oli sama kuin minulla eli kansainvälinen viestintä. Ploman teki uraansa läheisessä yhteydessä yleisradioyhtiöiden ja kansainvälisten järjestöjen kuten UNESCO:n kanssa.

Tuossa Lontoon kokouksessa Ploman haki vastausta globaalin muutoksen hallintaan demokraattisella tavalla viestinnän, koulutuksen, yhteiskuntatutkimuksen ja politiikan keinoilla. Globaalin oppimisen filosofia oli vasta alkuvaiheessaan. Ploman tarkoitti käsitteellä kahta asiaa:

- globaaleista asioista ja prosesseista oppimista, sekä

- oppimista globaalina, kokonaisvaltaisena prosessina.

Globaalit ongelmat nousivat 1980-Iuvun tieteellisessä keskustelussa uudella tavalla huomion kohteiksi. Esimerkiksi Nobel-palkittu, vuonna 1984 kuollut venäläinen ydinfyysikko Pjotr Kapitsa yhdisti taitavasti tieteellistä ja taiteellista osaamista niin idän ja lännen välisen jännityksen ratkaisemiseksi kuin Baikal-järven ekologiseksi suojelemiseksi (Bulletin of the Atomic Scientists 1984).

Lontoon seminaarissa pohdittiin sitä, mitkä ovat inmisen biologiset ja sosiaaliset rajat yhä kasvavan informaation käsittelylle. Siellä myös kysyttiin, johtaako harkitsematon sähköisen informaatioteknologian soveltaminen jo teollisen vallankumouksen aikana alkaneeseen inhimillisten ammattitaitojen lisääntyvään katoamiseen.

Keskeistä Plomanin mielestä oli oppimisen käsite: "Meidän täytyy oppia oppimisesta ja opettaa oppimista, mikä myös tarkoittaa, että meidän täytyy oppia kuinka käsitellä informaatiota, ellemme halua joutua samanaikaiseen informaation ylitarjonnan ja sen alikäytön ansaan." Tässä hän ilmaisi 2000-luvun uusien lukutaitojen ydinasian.

Plomanin näkemyksissä oli kestävää viisautta: "Mitä tahansa teemmekin, meidän täytyy ajatella ja toimia solidaarisuuden pohjalta saman planeetan asukkaina. Solidaarisina paikassa, horisontaalisesti, mutta myös ajassa, vertikaalisesti. Meidän tulee olla vastuussa tuleville sukupolville kahden kriteerin mukaisesti: moninaisuudessa, jota tarvitaan uusien optioiden ja vaihtoehtojen löytämiseksi, ja laadussa siten, ettemme jätä planeettaa huonommassa kunnossa, kuin minkälaisena itse olemme sen saaneet haltuumme."

(Varis 1995, 113-114) 
Vuonna 1992 YK-yliopisto julkaisi Plomanin muiston kunniaksi teoksen "Environmental change and international law: New challenges and dimensions" (Weiss 1992). Kuolleessaan 1990 Ploman oli mukana tekemässä tuota kirjaa ja liitteenä julkaistiin Ploman luonnehdinnat globaalin oppimisen käsitteestä ja sovellutuksista. Esitän seuraavassa lyhyesti hänen pääajatuksiaan soveltaen niitä omiin käsityksiini.

\section{G}

lobaalin oppimisen substanssi perustuu monen oppiaineen ja kulttuurin pitkään kokemukseen. Ongelmaksi on kuitenkin muodostunut se, että konventionaaliset kasvatuksen ja koulutuksen muodot eivät enää pystyneet vastaamaan tiedon nopean vanhenemisen synnyttämiin ongelmiin eivätkä uusien tiedon jakamisen ja kehittämisen menetelmiin.

Samanaikaisesti alettiin ymmärtää, että oppiminen on itse asiassa paljon perustavalaatuisempaa ja sisällyksekkäämpää intellektuaalista toimintaa kuin kasvatus tai koulutus. UNESCO ja Rooman Klubi korostivat raporteissaan oppimisen rajattomuutta - myöhempinä vuosikymmeninä UNESCO on puhunut oppimisen ilosta. Osallistavalla oppimisella (participatory learning) pyrittiin luomaan paikkaan liittyvää solidaarisuutta. Sen tavoitteena oli eri ihmisryhmien välisen informaation jakamisen prosessi. Ennakoiva oppiminen (anticipatory learning) pyrki aikaan liittyvän solidaarisuuden edistämiseen pyrkimällä ennakoimaan uusia, aikaisemmin esiintymättömiä tilanteita ja luomaan uusia vaihtoehtoa. Raporteissa puhuttiin myös yhteisöllisestä oppimisesta (societal learning), jonka yhteyttä yksilölliseen oppimiseen ei ole kunnolla selvitetty.

Ploman kritisoi perinteistä, kapea-alaista länsimaista oppimiskäsitystä. Antropologia sen sijaan lähestyi oppimista Plomanin mielestä laajaalaisesti: koska kaikki kulttuurit ovat opittuja, niillä täytyy olla oppimisen ulottuvuus ja niitä voidaan tarkastella myös oppimisprosesseina. Tuohon aikaan YK-yliopiston rehtorina toiminut indonesialainen professori Soedjatmoko tarkasteli koko kehitysprosessia ensisijaisesti oppimisprosessina.

Tällaisiin lähtökohtiin perustuen Ploman näki oppimisen holistisena ja globaalina ilmiönä. Globaali ylitti sellaiset traditionaaliset käsitteet kuten kansainvälinen, joka perustuu kansallisvaltioihin. Ploman näki, että muotoutumassa oleva uusi maailmanjärjestys ei johda vain vaikeisiin poliittisiin, taloudellisiin, ja ekologisiin ongelmiin, vaan myös laajamittaiseen sivilisaation muutokseen.

Plomanille horisontaalinen lähestymistapa merkitsi eri tieteenalojen, ideologioiden ja kulttuurien välisen tiedon integrointia ja tieteellisen, ammatillisen, ja eksponentiaalisesti kasvavan tiedon yhdentämistä. Vertikaalinen lähestymistapa merkitsi puolestaan eri tasoisten ongelmien paikallisesta planetaarisiin - käsittelemistä ja integroimista.

Kaikki Plomanin esittämät uudet ajatukset tulivat perinteisen yliopistomaailman ulkopuolelta. Myöskään hänen oma toimintansa ei oikein istunut vallitsevaan tiedejärjestelmään. Plomanille globaali oppiminen perustui kolmeen olettamukseen. Suhteessa sellaisiin perinteisiin käsitteisiin kuten kasvatus ja koulutus, oppiminen on laajempaa ja syvempää kuin koskaan aikaisemmin. Sitä on tarkasteltava suhteessa erilaisiin aikajänteisiin. Hallitukset ja televisio, joka oli sympoisumme pohdinnan kohde, liikkuvat lyhyen aikavälin asioissa, taloudelliset syklit ja kirjastot laajemmissa aikaväleissä. Sen sijaan ympäristö ja ekologiset aikajaksot ylittävät sukupolvien, vuosisatojen ja vuosimiljoonien kausia. Rakenteellisesti tarkasteltuna yhteiskunnallisen ympäristön muodostavat järjestelmät kuten uskonto, talous, hallitus, puolustuslaitos, sekä joukkoviestintä ovat perustehtäviensä lisäksi myös oppimisjärjestelmiä

Toinen olettamus on, että globaalin oppimisen intellektuaaliset ja käsitteelliset yhteydet eivät perustu vain ajankohtaisiin kysymyksiin. Ihmisen säilymisen kannalta globaalit talouden, demografian, ja ekologian keskinäisriippuvuudet ovat ratkaisevia haasteita edistykselliselle ajattelulle. Ploman kirjoitti, että "kaikkein iskevin globaalin oppimisen tieteellis-intellektuaalisen yhteyden piirre on reaktio perinteisiä läntisiä ajattelumalleja vastaan ja siitä seuraava intellektuaalisen ilmapiirin muutos." Tieteelliset yhteisöt läntisen kulttuurin ulkopuolella olivat jo ohittamassa länsimaista lineaarista, determinististä ja reduktionistista todellisuuskäsitystä. Uuden ajatukset sattumasta, avoimuudesta, epälineaarisuudesta ja stokastisista prosesseista olivat luomassa uutta käsitystä yllätyksen, riskin, löytämisen, ja luovuuden merkityksestä.

Tuohon aikaan teoreettisen fysiikan Nobelpalkittu, pakistanilainen Abdus Salam kirjoitti tieteen ja teknologian kehittymisestä ihmiskun- 
nan historiassa syklisinä prosesseina. Sen ydinalue on ollut vain vähän aikaa läntisissä kulttuureissa. Tosiasiassa kysymyksessä on ihmiskunnan yhteisestä, keskinäisesti jaetusta perinnöstä (Salam 1990)

Kolmas olettamus viittasi syntymässä olevaan palvelutalouteen tai teknokraattiseen, tietoyhteiskuntaan. Plomanille oli selvää, että tällainen yhteiskunta eroaisi perinpohjaisesti teollisuusyhteiskunnan toiminnasta. Teknologia mahdollistaa tieteellisten löytöjen soveltamisen suoraan. Keskusteluissa ei vielä 1980-luvun puolivälissä näkynyt nykyisten tietoyhteiskuntafilosofien kaltaisia visionäärejä, mutta kehityksen suunta arvioitiin aika hyvin.

Jäähyväisluennossaan hollantilaisessa Delftin teknologiayliopistossa vuonna 2002 professori William Melody käsitteli informaatioon ja tietoon perustuvan talouden uusia haasteita. Hän totesi, että kun maatalousvaltaisessa taloudessa sijoituspääomaa kiinnosti maa ja teollisuusyhteiskunnassa koneet ja laitteet, niin tietoon perustuvassa taloudessa muodostuvat osaavat ihmiset sijoitustoiminnan kohteiksi. Tämä johtuu siitä, että inmiset tuottavat, varastoivat ja soveltavat tietoa - koneet eivät sitä tee.

Teollisessa taloudessa työvoimaa käytettiin fyysisen toiminnan tarpeitten mukaisesti, mutta tietoon perustuvassa taloudessa inhimilliset taidot, kompetenssit ja kyvyt muodostuvat keskeisiksi voimavaroiksi. "Työvoimasta" tulee Melodyn näkemyksen mukaan "tietotyöläisiä" ja ammattikasvatuksen, koulutuksen, sekä niihin liittyvän tutkimuksen ja kehitystyön rooli voimistuu (Melody 2002).

Jobaali e-oppiminen liittyy pyrkimyksiin humanisoida nykyistä globalisaatiokehitystä sellaiseksi, joka perustuisi välittämiseen sekä tiedon ja osaamisen jakamiseen perustuvaan solidaarisuuteen. Keskeisiä periaatteita tällä hetkellä on seitsemän: osaamisen ja tiedon kuilun kaventaminen, ajatusten vapaan liikkuvuuden lisääminen, informaatio- ja viestintäteknologian käytön lisääminen, kestävän kehityksen edistäminen, opettajankoulutuksen lisääminen, aivoviennin pysähdyttäminen maailmassa, sekä kulttuurisen moniarvoisuuden turvaaminen. Kansojen välistä dialogia uhkaa erityisesti kasvava digitaalinen kuilu (digital divide) ja lukutaidottomuus (UNESCO 175 EX/5 Add. 15 September 2006)

Euroopan e-oppimisen portaali perustuu aja- tukseen, että digitaalinen lukutaito ja mediakasvatus ovat yhä keskeisiä vaatimuksia, jotta kansalaiset voisivat toimia tietoyhteiskunnassa. Tarve ei rajoitu vain teknologisen osaamisen aiheisiin, vaan kysymys on laajemmassa mielessä kansalaisten osallistumismahdollisuuksista, kehittyä inmisinä ja viestintävälineiden kriittisen käytön oppimisesta. Tutkimusryhmät pyrkivät edistämään digitaalisen lukutaidon tuntemusta maailmalla hakemalla vastausta neljään peruskysymykseen: miksi (medialukutaidon perusteet), mitä (määritelmät), missä (opinto-ohjelmat ja instituutiot) sekä kuinka (pedagogiikka ja käytäntö). Unescon ja EU:n tukema Mentor Association -ryhmä kokee myös länsimaisten kielten dominaation ongelmaksi ja se suosittelee erityisesti espanjan, portugalin ja arabiankielisten palvelujen lisäämistä. Olen itse tässä ryhmässä tänä keväänäSaudi-Arabiassa puhumassa Persian lahden alueen ministereitten ensimmäisessä mediakasvatuskokouksessa.

Espanjalainen Jose Manuel Perez Tornero yhdistää digitaalisen lukutaidon käsitteessä intellektuaalisia kompetensseja (perseptiot, kognitiiviset ja emotionaaliset kompetenssit) sekä käytännöllisiä kompetensseja (fysiologiset ja motoriset kompetenssit) (Perez Tornero 2004). Tavoitteena on uuden "teknen" saavuttaminen, joka antiikin Kreikassa merkitsi taiteen ja käsityötaidon osaamista, sekä aineellisen maailman muokkaamiseen tarvittavia välineitä että käsitteellisiä ja kognitiivisia välineitä käsitellä informaatiota, kuin myös yhteiskunnallisia välineitä tai instituutioita yhteiskunnan järjestämiseksi. Perez Tornero havaitsee, että toimintaympäristön ja aistien roolin muutos vaikuttaa myös henkisiin toimintoihimme, ajattelutapoihin.

European Education Partnership (E.E.O.) on kehitellyt mallia, joka auttaisi ymmärtämään informaatio-ja kommunikaatioteknologiaan perustuvan nykyisen pedagogiikan (ICT-rich pedagogy) ja aikaisemman, 1900-luvun pedagogiikkaan välisiä eroja (www.eep.edu.org). Uudessa pedagogiikassa korostuvat aikaisempaa enemmän esimerkiksi yleiset kasvatustaidot erikoisalojen korostuksen sijaan, opetuksen valmistaminen yhteistoiminnallisesti opettajan yksilösuorituksen sijaan, lähteiden hakeminen yhdessä oppijoitten kanssa, ulkopuolisen maailman ja vertaisryhmän merkityksen korostuminen oppimisen lähteinä luokkahuonekokemuksen sijaan jne. Oppijat eivät myöskään uudessa oppimisympäristössä odo- 
ta opettajilta valmiita vastauksia, vaan apua sellaisten valmiuksien hankkimisessa, joilla vastauksia etsitään itse. Tutkintoja ja arviointeja ei tehdä vain tiettyinä aikoina vuodessa, vaan silloin, kun oppilaat ovat siihen valmiita. Tutkinnot ovat yhä tärkeitä, mutta osaaminen painottuu työelämässä entistä enemmän.

udet käsitteet, kuten monilukutaito ja monimediaalisuus sijoittuvat vaikeasti vanhoihin ajattelutapoihin. Moniälykkyysteoriaa kehitellyt professori Howard Gardner kirjoitti vuonna 2003 häneltä usein kysytyn sitä, mistä hän keksi ajatuksen moniälykkyyksistä. Totuudenmukaisin vastaus hänestä on, ettei hän sitä tiedä. Mutta koska tällainen vastaus ei tyydytä kysyjää eikä häntä itseäänkään, Gardner pohti asiaa. Hän totesi olleensa nuorena vakavasti otettava pianisti sekä muistakin taiteenaloista innostunut. Kun hän aloitti kognitiivisen ja kehityspsykologian opintoja, häntä hämmästytti se, ettei taiteista tässä yhteydessä mainittu mitään. Gardner kirjoitti pitäytyvänsä yhä tunnistamissaan älykkyyden ulottuvuudessa, mutta sanoi kiinnostuksen emotionaalisen älykkyyden ohella kasvaneen spirituaalisen älykkyyden ja seksuaalisen älykkyyden tunnistamiseksi omiksi ominaisuuksikseen. Lisäksi Garder totesi kollegoittensa perustelleen digitaalisen älykkyyden määrittelyä omaksi lajikseen (Gardner 2003).

Digitaalisiin kompetensseihin on liitetty sellaisia ominaisuuksia, kuten tietokoneisiin ja opetusteknologiaan liittyvät perusvalmiudet, hypermediakieleen ja merkkeihin liittyvät kognitiiviset kompetenssit, telemaattisiin ja virtuaalisiin toimintoihin liittyvät kompetenssit, interaktiivisen median ja on-line oppimisen taidot ja kybertilaan liittyvät globaalin yhteiskunnan viestintävalmiudet ja herkkyys monikulttuurisen maailman ilmiöihin.

Taitoihin ja kompetensseihin liittyvä käsitteistö on vielä horjuvaa. Taidot nähdään usein vain alempiarvoisina ominaisuuksina, kuten tietokoneiden käsittelytaitoina, mutta joskus vaativampina ominaisuuksina kuten kriittisinä ajattelutaitoina. Kompetenssilla viitataan usein tietyissä yhteyksissä tapahtuviin taitoihin, mutta joskus sitä käytetään myös taitojen synonyymina.

Eurooppalaisessa ajattelussa korostuvat keskeiset kompetenssit. Nämä muodostuvat tiedosta, taidoista ja asenteista. Ne ovat osittain perittyjä, mutta myös kulttuurin ja ympäristön kautta hankittuja ominaisuuksia. Lukutaitomallin ulottuvuuksien ja kompetenssien hankkimisen yhdistämisellä voidaan hahmottaa digitaalisen kulttuurin muutosprosesseja. Geneeriset, keskeiset kompetenssit mahdollistavat menestyksellisen elinikäisen toiminnan. Ne ovat siirrettävissä moniin yhteyksiin ja tilanteisiin ja ne ovat moniulotteisia siten, että niitä voidaan käyttää useiden tavoitteiden toteuttamiseen, erilaisten ongelmien ratkaisemiseen ja erilaisten tehtävien suorittamiseen. Keskeiset kompetenssit ovat edellytyksiä henkilökohtaiselle menestymiselle sekä työelämässä että elämässä ja oppimisessa yleensä. (European Commission 2004).

Kulttuurisen muutoksen toteuttaminen edellyttää kuitenkin sekä uusia suoritustapoja että suunnittelua ja oppimisen uudelleenjärjestelyä. Dialogin ja vuorovaikutuksen taidot korostuvat uusissa suoritustavoissa. Toiminnassa korostuu muutoksen johtaminen aktiivisen ajattelun avulla. Taiteen, tieteen ja teknologian yhdistyminen synnyttää uuden renessanssikasvatuksen tarpeen. Sen ei tarvitse merkitä katseen suuntaamista taaksepäin, kulttuurin kadonneeseen loistoon, vaan uusi renessanssikasvatus voi suuntautua myös tulevaisuuteen, uutta luovaan, hyvän elämän rakentamiseen. Nykyajan multimedian tallennusja levitysmuodoilla, monikulttuurisen viestinnän kompetenssien ja globaalin teknologian avulla mahdollisuudet globaaliin oppimiseen ovat koko inmiskunnan historiaan verrattuna ainutlaatuiset muutenkin kuin globaalisten katastrofien kautta.

Meidän tehtäväksemme jää ratkaista ristiriita globaalin kilpailukyvyn vaatiman tuotannon tehokkuuden ja humanismia korostavien kasvatuksellisten arvojen välillä. Tuosta jännitteestä saattaa kuitenkin löytyä yliopistojenkin tarvitsemaa energiaa ja elinvoimaa.

\section{Lähteitä}

Bulletin of the Atomic Scientists, Pyotr L. Kapitsa 1894 - 1984, June-July 1984, Vol. 40, N:0 6.

EK: Kansainvälistyminen haastaa koulutusjärjestelmän - painopiste putkitutkinnoista koulutusmoduuleihin. Tiedote 18.10.2006.

Feldstein, Michael (2006). The Digital Promise: Using Technology to Transfrom Learning. eLearn Magazine, http://elearnmag.org, September 19/2006. 
Gardner, Howard: Multiple Intelligences After Twenty Years. Paper presented at the American Educational Research Association, Chicago, Illinois, April 21, 2003.

Gutierrez Diaz, Maruja (2006). The genesis and evolution of the EU eLearning initiative. In Communication and learning in the multicultur-al world - Festschrift for Professor Tapio Varis, edited by Pekka Ruohotie and Rupert Maclean, University of Tampere.

Heikkinen, Anja (2000). Suomalaisen ammattikasvatuksen alkuvaiheita. Teoksessa Suomalaisen ammattikasvatuksen historia, Okkasäätiö.

Glotz, Peter (1996). Im Kern verrotet? Fünf vor zwölf an Deutschlands Universitäten. Stuttgart: Deutsche Verlags-Anstalt.

ICDL International Conference on Digital Libraries, New Delhi 5-8 December 2006.

InterMedia: Edward Ploman 1926-1990, November/December 1990, Vol.18, Isse 6, 42-43.

Järvelä, Sanna - Päivi Häkkinen, Erno Lehtinen (toim. 2006). Oppimisen teoria ja teknologian opetuskäyttö. WSOY Oppimateriaalit Oy.

Melody, William: The triumph and tragedy of human capital: Foundation resource for the global knowledge economy. Farewell Address, Delft University of Technology, 31 May 2002.

Niemi, Hannele (2002). Kasvatustieteen eettinen vastuu yhteiskunnassa. Teoksessa Kasvatustiede Suomessa 150 vuotta, toim. Michael Uljens.

Perez Tornero, Jose Manuel: Promoting Digital Literacy. European Commission $4^{\text {th }}$ Workshop "Media Literacy, Digital Literacy, eLearning", 27 February 2004 Brussels

Puhakka, Antero (2006). Jäähyväiset sivistysyliopistolle. Acatiimi N:o 7/06.

Pusey, Michael (1987). Jürgen Habermas. Routledge.

Rauner, Felix: A Reflex on the Stigmatisation of VET. UNESCO-UNEVOC Vocational Content in Mass Higher Education? Responding to the challenges of the labour market and the workplace. International Conference, 8-10 September 2005, Bonn, Germany, Final Report.

Ruohotie, Pekka: Ammattikasvatuksen yliopis- tollinen opetus ja tutkimus. Teoksessa Suomalaisen ammattikasvatuksen historia, Okka-säätiö 2000.

Salam, Abdus: Notes on Science, Technology and Science Education in the Development of the South. The Third World Academy of Sciences, April 1990.

The Danish National Commission for Unesco (2006). Capacity Building in Higher Education and Research on a Global Scale.

The Open University Scenarios 2003-2012. The Open University, Milton Keynes 2003.

The Times of India: Business Class - Treat Education as an Enterprise. 6 December 2006.

UNESCO-UNEVOC: Vocational Content in Mass Higher Education? Responses to the Challenges of the Labour Market and the Work-Place. International Seminar held in Bonn, 8-10 September 2005.

UNESCO Report by the Director-General on the Follow-up to Decisions and Resolutions adopted by the Executive Board and the General Conference at their previous sessions. 175 EX/5 Add., Paris, 15 September 2006

UNESCO Forum: Second International Colloquium on Research \& Higher Education Policy, Paris 29. November-1. December 2006.

Varis, Tapio (1984). The Influence of International Television: a Case Study. Journal of Moral Education, Vol. 13, No 3.

Varis, Tapio (1995). Tiedon ajan media. Yliopistopaino.

Varis, Tapio (toim. 2005). Uusrenessanssiajattelu, digitaalinen osaaminen ja monikulttuurisuuteen kasvaminen, Okka-säätiö.

Varis, Tapio (2006). Ammatillisen osaamisen intellektuaaliset haasteet. Ammattikasvatuksen aikakauskirja, No 1, 06.

Weiss, Edith Brown (ed. 1992). Environmental Change and International Law: New Challenges and Dimensions. The United Nations University, Tokyo.

Näkökulma perustuu ammattikasvatuksen professorin Tapio Variksen virkaanastujaisesitelmään Tampereen yliopistossa 15.12.2006. Viran alamääreenä on "erityisesti kansainvälistyvät oppimisympäristöt". 